\title{
Transcriptome provides potential insights into how calcium affects the formation of stone cell in Pyrus
}

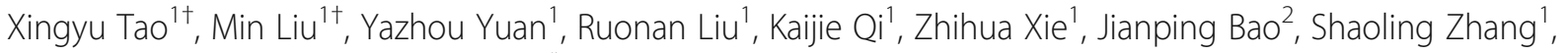
Katsuhiro Shiratake ${ }^{3}$ and Shutian Tao ${ }^{1 *}$

\begin{abstract}
Background: The content of stone cells in pears has a great influence on taste. Stone cells are formed by the accumulation of lignin. The treatment of exogenous calcium can affect the lignin synthesis, but this Ca-mediated mechanism is still unclear. In this study, the author performed a comparative transcriptomic analysis of callus of pears (Pyrus $x$ bretschneideri) treated with calcium nitrate $\mathrm{Ca}\left(\mathrm{NO}_{3}\right)_{2}$ to investigate the role of calcium in lignin synthesis.

Results: There were 2889 differentially expressed genes (DEGs) detected between the Control and $\mathrm{Ca}\left(\mathrm{NO}_{3}\right)_{2}$ treatment in total. Among these $2889 \mathrm{DEGs}$, not only a large number of genes related to Ca single were found, but also many genes were enriched in secondary metabolic pathway, especially in lignin synthesis. Most of them were up-regulated during the development of callus after $\mathrm{Ca}\left(\mathrm{NO}_{3}\right)_{2}$ treatment. In order to further explore how calcium nitrate treatment affects lignin synthesis, the author screened genes associated with transduction of calcium signal in DEGs, and finally found CAM, CML, CDPK, CBL and CIPK. Then the author identified the PbCML3 in pears and conducted relevant experiments finding the overexpression of PbCML3 would increase the content of pear stone cells, providing potential insights into how Ca treatment enhances the stone cell in pears.
\end{abstract}

Conclusions: Our deep analysis reveals the effects of exogenous calcium on calcium signal and lignin biosynthesis pathway. The function of PbCML3 on stone cells formation was verified in pear.

Keywords: Pears, Stone cell, Lignin, Transcriptome, Calcium

\section{Highlights}

-The content of lignin in pear callus treated with $0.5 \%$ calcium nitrate will increase.

-A large number of DEGs enriched in secondary metabolic pathways implies a calcium-lignin regulatory network.

-Overexpression of $P b C M L 3$ in pears increased the content of stone cells in fruits.

\footnotetext{
*Correspondence: taost@njau.edu.cn

${ }^{+}$Xingyu Tao and Min Liu contributed equally to this work.

'State Key Laboratory of Crop Genetics and Germplasm Enhancement,

Nanjing Agricultural University, Nanjing 210095, China

Full list of author information is available at the end of the article
}

\section{Introduction}

Pear is one of the most popular fruits in the world. Stone cells, are an important factor influencing the mouthfeel of the pear fruit, comes from pear parenchyma cells which undergo programmed cell death, thickening of secondary cell walls, and deposition of cellulose and lignin [1]. And lignin deposition is an important process to form stone cells [2]. Therefore, regulation of lignin accumulation is the key to reduce the content of stone cells. Lignification is a unique process of higher plants. Its main function is to provide plant morphological support and improve plant resistance to

(c) The Author(s). 2021 Open Access This article is licensed under a Creative Commons Attribution 4.0 International License, which permits use, sharing, adaptation, distribution and reproduction in any medium or format, as long as you give appropriate credit to the original author(s) and the source, provide a link to the Creative Commons licence, and indicate if changes were made. The images or other third party material in this article are included in the article's Creative Commons licence, unless indicated otherwise in a credit line to the material. If material is not included in the article's Creative Commons licence and your intended use is not permitted by statutory regulation or exceeds the permitted use, you will need to obtain permission directly from the copyright holder. To view a copy of this licence, visit http://creativecommons.org/licenses/by/4.0/ The Creative Commons Public Domain Dedication waiver (http://creativecommons.org/publicdomain/zero/1.0/) applies to the data made available in this article, unless otherwise stated in a credit line to the data. 
environmental stress [3]. Similar to most angiosperms, the composition of lignin in pear stone cells is mainly composed of guaiacyl-lignin (G-lignin), with a small amount of syringyl-lignin (S-lignin) and phydroxyphenyl lignin (H-lignin) [4]. The branching of phenylpropanol metabolism synthesizes three monoalcohols, and then oxidatively polymerizes them into lignin polymers [5], in which calcium is used to affect stems stiffness and stone cells content in plant $[6,7]$.

However, how calcium regulates the formation of stone cells is still unclear. Many studies have shown that exogenous calcium treatment has an effect on secondary metabolic synthesis of plants, especially lignin synthesis. The main genes activated after exposure to calcium chloride in pear (Pyrus spp. L.) leaves are enriched in secondary metabolic pathways [8]. Exogenous calcium was found to regulate the phenylalanine pathway in peony (Paeonia lactiflora P.) inflorescence stems [9], increase stems thickness of roses (Rosa hybrida L.) [10], and enhance the stiffness of chrysanthemum (Chrysanthemum morifolium R.) stems [7]. In addition, the bending of the gerbera (Gerbera jamesonii T.) stem is delayed by exogenous calcium treatment. This may be due to the accumulation of lignin and the coupling of pectin molecules, resulting in the harder cell wall [11]. Moreover, a significant increase in the mechanical strength of the inflorescence stems was found in P.lactiflora after exogenous calcium treatment, which might be caused by changes in cell wall composition [12]. In addition, the intracellular imbalance of $\mathrm{Ca}^{2+}$ triggers the development of hard end disorder in pear (Pyrus pyrifolia $c v$. 'Whangkeumbae') [13]. The lignification process is considered to be affected by calcium, however, the specific mechanism of the effect of exogenous calcium on lignin synthesis is still unclear.

Calcium is mainly found in cell walls and is a basic signal molecule. It plays an important role in regulating plant growth and development [14]. As an essential nutrient, $\mathrm{Ca}$ also plays a prominent role in maintaining the structure and function of the cell wall [15]. In order to maintain cell wall integrity and promote plant growth and development, exogenous $\mathrm{Ca}$ treatment is usually used to regulate gene expression [16, 17]. In addition, this positive effect of $\mathrm{Ca}$ may be related to calcium ion $\left(\mathrm{Ca}^{2+}\right)$ sensors [18]. $\mathrm{Ca}^{2+}$ is a ubiquitous second messenger, involved in a variety of cellular processes. The intracellular free $\mathrm{Ca}^{2+}$ concentration will change after plants perceive environmental changes. The changes of calcium ions are different for stimulation of different nature, intensity and duration, and the whole biological reaction process requires the decoding and relay of $\mathrm{Ca}^{2+}$ sensors [19-21]. Calcium-binding proteins, is a receptor for $\mathrm{Ca}^{2+}$ signaling, which is mainly divided into three categories: (1) calmodulin protein ( $\mathrm{CaM})$ and calmodulin- like protein (CML); (2) calmodulin phosphatase B protein (CBL); (3) calmodulin-dependent protein kinases (CDPK) [22].

$\mathrm{CaM}$ is the most widely distributed and most important calcium-binding protein. The physiological function of CaM has been extensively studied. It participates in the process of photosynthesis, regulates enzyme activity, cell division and differentiation, cell movement and gene expression [23].. As calmodulin-like protein, CML is also the main sensor of $\mathrm{Ca}^{2+}$, which regulates various cell functions by regulating the activity of different target proteins. At present, family members of $50 \mathrm{CMLs}$ and 32 CMLs were identified respectively in model plants arabidopsis and rice [24, 25]. Current studies show that CML plays an important role in plant growth and resistance through multiple interactions, such as regulating the morphology and division of plant cells [26, 27], promoting the plant innate immunity through flagellindependent signaling pathways [28], responsing to salt, drought and low-temperature stress, etc. [29]. In Rosaceae, CMLs are widely expressed in apples, including roots, stems, leaves, flowers and fruits, and are spatially specific [30]; however, there are few reports of CML in pears.

Here, we performed exogenous calcium treatment and transcriptome sequencing on pear callus, and analyzed the differences in gene expression levels after treatment. Based on the up-regulated of a large number of transcription factors, the hypothesis that exogenous calcium affects the lignin biosynthesis by regulating transcription factors is further confirmed [9]. In addition, we report a novel $P b C M L 3$ gene that plays a central role in lignin accumulation and stone cells formation. However, the specific regulation mechanism of CML on lignin systhesis needs further study.

\section{Materials and methods \\ Plant materials and treatment}

Trees of thirty-year-old Pyrus bretschneideri 'Dangshansuli' (white pear group), grown on $P$. betulaefolia rootstocks in an orchard in Baoying County, Jiangsu Province, China, were used in this study. Fruit samples were collected from the same trees, 10 days after full bloom (DAF). The collected pulp was cultivated for callus.

Tobacco (Nicotiana benthamiana L.) which were planted in potting medium or solid agar media and were grown in a room with constant temperature $\left(25^{\circ} \mathrm{C}\right)$ under a 16-h light/8-h dark cycle and a relative humidity of $40-60 \%$.

\section{Callus culture}

Young fruits with good quality, no mechanical damage and the same size after 10 days of flowering were rinsed 
repeatedly with tap water to clean the surface and remove impurities, and then rinsed several times with distilled water. Green fruits were immersed in anhydrous ethanol (75\%) for 30s in the bechtop, then soaked in sodium hypochlorite (9\%) solution for $10 \mathrm{~min}$ for disinfection. All petri dishes were sterilized in distilled water with high-temperature sterilization for 3-5 times. After being peeled with a scalpel, and the pulp far from the core was cut into thin and even pieces and inoculated into the induction medium for induction culture.

The callus culture medium formulation has been improved and optimized, namely: MS $4.74 \mathrm{~g} / \mathrm{L}+1.5 \mathrm{mg} / \mathrm{L}$ 2, 4-d + $0.5 \mathrm{mg} / \mathrm{L} \mathrm{NAA}+0.2 \mathrm{mg} / \mathrm{L} \mathrm{TDZ}+7 \mathrm{~g} / \mathrm{L}$ AGAR $+30 \mathrm{~g} / \mathrm{L}$ sucrose $+10 \mathrm{~g} / \mathrm{L}$ sorbitol $+0.1 \mathrm{mg} / \mathrm{L} \mathrm{VC}$, and $\mathrm{pH}$ was 5.8. The culture medium was bottled and sterilized at $121^{\circ} \mathrm{C}$ for $20 \mathrm{~min}$. The callus subculture was carried out on the ultra-clean working table. The culture temperature should not exceed $25{ }^{\circ} \mathrm{C}$, protecting from light.

\section{Calcium treatment of callus}

Basing on tissue differentiation MS medium, different concentrations of exogenous calcium nitrate were added: $0,0.1,0.5 \%$. Callus with good growth condition and consistent growth were selected and inoculated in the new medium. Cut the good callus into uniform callus with a thickness of about $0.1 \mathrm{~cm}$ and lay it on the medium to make it fully contact with exogenous calcium. Calcium treatment was carried out on the ultra-clean working table, and the temperature of callus culture should not exceed $25^{\circ} \mathrm{C}$. The culture cycle was 15 days, and samples were taken every 5 days. The culture medium attached to the callus was washed with distilled water, frozen with liquid nitrogen, and stored in a refrigerator at $-80^{\circ} \mathrm{C}$ for testing. Callus without treatment was used as control (CK). Observe the callus before each sampling and photograph callus with obvious changes in growth characteristics. Callus growth state, change of apparent color and degree of looseness were recorded. Compare and statistically analyze the effect of different treatments on callus growth state.

\section{Determination of lignin content}

A suitable amount of dried samples was put into the grinding machine for grinding. After that, $0.01 \mathrm{~g}$ of the sample was accurately weighed and added about $1 \mathrm{ml}$ of absolute ethanol to the mortar, then grinding it thoroughly into a homogenate. Then, the samples were transferred to a $2 \mathrm{ml}$ centrifuge tube, and fixed with anhydrous ethanol. After centrifugation at $12000 \mathrm{r}$ for 2 min, discard the supernatant, add $2 \mathrm{ml}$ of absolute ethanol and repeat the above steps. After repeating three times, add 1:2 volume ratio of alcohol and n-hexane to wash the precipitate and repeat three times. The centrifuged samples were air-dried at room temperature. The dried sample was transferred to a new $10 \mathrm{ml}$ centrifuge tube, and $2 \mathrm{ml}$ of acetyl bromide/acetic acid solution with a concentration of $25 \%$ was added. The sealing film was sealed and placed in a water bath at $70^{\circ} \mathrm{C}$ for $30 \mathrm{~min}$, which was inverted every $10 \mathrm{~min} .0 .9 \mathrm{ml} \mathrm{NaOH}$ $2 \mathrm{~mol} / \mathrm{L}$ was added to terminate the reaction. After adding $5 \mathrm{ml}$ acetic acid and $0.1 \mathrm{ml} 7.5 \mathrm{~mol} / \mathrm{L}$ hydroxylamine chloride, the volume was adjusted to $10 \mathrm{ml}$ with acetic acid. $0.1 \mathrm{ml}$ of the reaction solution was brought into a new $2 \mathrm{ml}$ centrifuge tube, diluting with $0.9 \mathrm{ml}$ acetic acid, and the absorbance value of the sample was determined at the wavelength of $280 \mathrm{~nm}$ with an enzymelinked immunoassay. The standard curve of lignin content was prepared with a standard sample of lignin, and the lignin content in each sample was calculated according to the standard curve (the standard products were purchased from Sigma company). The lignin content is expressed as a percentage of the measured value/the measured sample weight. The final data are expressed as mean \pm standard deviation.

\section{Determination of calcium content}

Microwave digestion combined with plasma emission spectrometry (ICP) was used to determine the calcium content in callus. Main experimental steps are as follows: soak the sterilizing tube in acid one day and overnight in advance, rinse the sterilizing tube with deionized water several times, put it on the tube rack, and dry it in the oven. The required volumetric flask, funnel and other instruments shall be cleaned by ultrasonic wave for 30 min. After taking them out, they be washed with deionized water and then dried. The dried samples weighed $0.1 \mathrm{~g} \times 3$, wrapped with weighing paper and marked. Put the measured sample in a sterilizing tube and add $8 \mathrm{ml}$ deionized water into the outer tube of the sterilizing tube, then add $2 \mathrm{ml}$ nitric acid into the sterilizing tube. Sterilize it in the instrument, cool it to room temperature, then open the sterilizing outer tube. Take out the sterilizing tube and add the sterilizing liquid into the corresponding $50 \mathrm{ml}$ volumetric bottle. Rinse the sterilizing tube with deionized water for 3 times, and finally, use the deionized water to determine the volume. Use $0.45 \mathrm{~m}$ filtering membrane of the water system and $5 \mathrm{ml}$ syringe for filtering. Use the filtrate for standby. About $10 \mathrm{ml}$ of the solution with a constant volume was taken and transferred to a $10 \mathrm{ml}$ centrifuge tube for testing. The results were measured by Prodigy inductively coupled plasma emission spectrometer.

Through the course of the callus development, its calcium content and lignin content were measured every 5 days covering nine developmental samples (S1, CK after 5 days; $\mathrm{S} 2,0.1 \% \mathrm{Ca}\left(\mathrm{NO}_{3}\right)_{2}$ treatment after 5 days; S3, $0.5 \% \mathrm{Ca}\left(\mathrm{NO}_{3}\right)_{2}$ treatment after 5 days; S4, CK after 10 
days; S5, $0.1 \%$ Ca $\left(\mathrm{NO}_{3}\right)_{2}$ treatment after 10 days; S6, $0.5 \% \mathrm{Ca}\left(\mathrm{NO}_{3}\right)_{2}$ treatment after 10 days; S7, CK after 15 days; $\mathrm{S} 8,0.1 \% \mathrm{Ca}\left(\mathrm{NO}_{3}\right)_{2}$ treatment after 15 days; and $\mathrm{S} 9,0.5 \% \mathrm{Ca}\left(\mathrm{NO}_{3}\right)_{2}$ treatment after 15 days).

\section{Transcriptome with RNA-Seq and data analysis}

The total RNA extracted from the pyrus callus of the Control and $\mathrm{Ca}\left(\mathrm{NO}_{3}\right)_{2}$ treatment at $\mathrm{S} 1 \sim \mathrm{S} 6$ using a MiniBEST Plant RNA Extraction Kit (TaKaRa, Kusatsu, Shiga, Japan) were used for transcriptome sequencing. The Beijing Genomics Institute (Shenzhen, China) used the Illumina HiSeq ${ }^{\mathrm{mix}}$ 4000 system (Illumina Inc., San Diego, California, USA) to prepare and sequence 18 libraries (S1 S6, 3 replicates). The sequence data were uploaded to NCBI and generated SRR number (Table S3). In view of the significant difference in the lignin content of callus on the 10th day of culture, S4 S6 were selected for detailed analysis under the same time dimension. After the original reading, Trimmomatic filter was performed by using the short reads assembling program Trinity, whose annotation was performed by using various bioinformatics databases, including nonredundant protein (NR), nonredundant nucleotide (NT), Interpro and gene ontology (GO), Kyoto encyclopedia of genes and genomes (KEGG) [31]. Cufflinks was used to calculate the FPKM after Tophat2 mapping and DESeq2 was used to screen for DEGs (Table S5), our criterion for screening was padj $<0.05$ [32]. The functions of DEGs were explored through GO and KEGG pathway analysis, and the q-value $\leq 0.05$ were defined as significant enrichment. This was to identify metabolic pathways that were significantly enriched.
Gene expression analysis with quantitative real-time PCR (qRT-PCR)

Total RNA of callus and fruit was extracted using the CTAB method, and genomic DNA contamination was removed by using DNase I (Invitrogen). Then $1 \mu \mathrm{g}$ of RNA was used for the synthesis of the first strand of cDNA using ReverTra Acealpha-First Strand cDNA Synthesis Kit (TOYOBO Biotech Co. Ltd.). qRT-PCR analysis and amplification were performed using Light Cycler 480 (Roche) and all reactions were performed according to the Light Cycler 480 SYBR GREEN I Master (Roche) reagent instructions. The relative expression levels were calculated by calculating the average threshold cycle $(\mathrm{Ct})$ for each sample using the $2^{-\Delta \Delta \mathrm{Ct}}$ method.

Gene primers were designed and amplified by using Premier 5.0 software (Table S1). In order to further verify the specificity of primers, the designed primers were examined by BLAST. Finally, the $\alpha$-tubulin (Pbr042345.1) was normalized as reference gene.

\section{Subcellular localization}

Tobacco leaves were transformed according to the method described by Sperschneider et al. (Sperschneider et al, 2017). The LB medium containing $50 \mathrm{mg} / \mathrm{L} \mathrm{KNA}$ and 100 mg/L RIP was connected to the activated Agrobacterium with sterilized lance and cultured in a constant temperature incubator at $28^{\circ} \mathrm{C}$ for $36 \mathrm{~h}$. Later, the Agrobacterium was collected by centrifugation and resuspended in the infiltration buffer (10 $\mathrm{mM} \mathrm{MgCl}_{2}, 10 \mathrm{mM}$ EMS, PH 5.7, $200 \mathrm{mM}$ Acetosyringone) to a final OD600 of 0.8-1.2. Then, the upper leaves were infiltrated after shaking at room temperature $\left(25^{\circ} \mathrm{C}\right)$ for $4 \mathrm{~h}$. After being cultivated for 3-4 days under normal growth conditions, finally, we used a confocal laser scanning microscope (Zeiss LSM 700, Jena, Germany) to examine the infiltrated leaves.
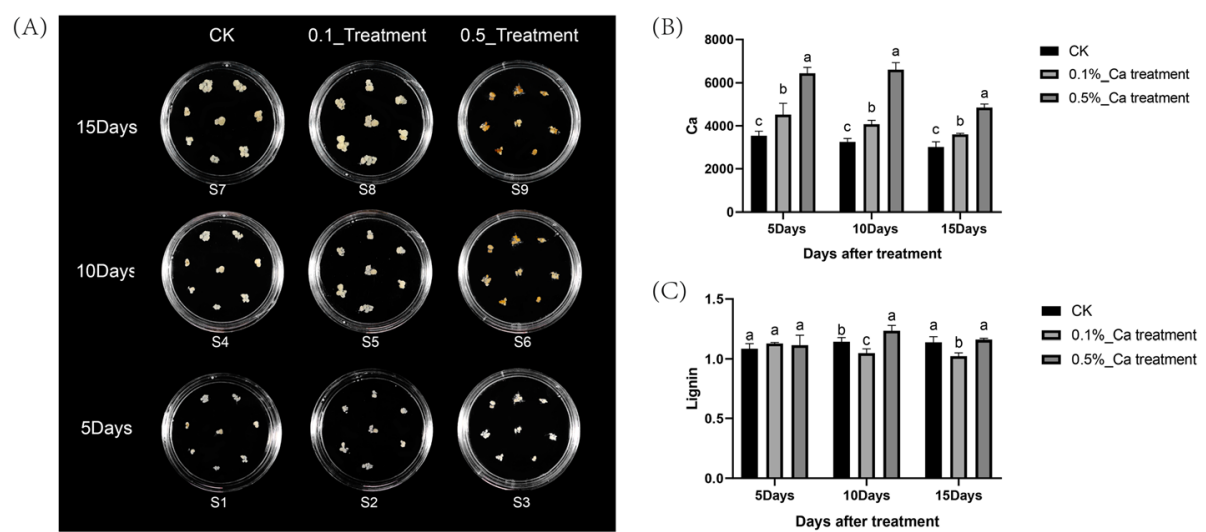

Fig. 1 Callus photographs, calcium and lignin content on different treatments. (A) Callus treated with different calcium concentrations on 5th, 10th and 15th day. (B) Calcium content on different treatments at three stages in callus. (C) Lignin content on different treatments at three stages in callus 


\section{The function of gene in pome fruit}

According to the method from Xue et al. [33], $35 s$ $p b C M L 3-g f p$ was injected with a needle for the transformation of the pear, and the solid LB medium containing $50 \mathrm{mg} / \mathrm{L} \mathrm{KNA}$ and $100 \mathrm{mg} / \mathrm{L}$ RIP was used to activate the bacteria, which was then cultured in an incubator of constant temperature at $28^{\circ} \mathrm{C}$ for $36 \mathrm{~h}$. The monoclonal points on the line of the incubator were selected with the sterilized toothpick, and then the solid LB medium containing $50 \mathrm{mg} / \mathrm{L} \mathrm{KNA}$ and $100 \mathrm{mg} / \mathrm{L}$ RIP was lined for secondary activation and cultured in an incubator at $28^{\circ} \mathrm{C}$ for $36 \mathrm{~h}$. The reactivated agrobacterium was scratched into $30 \mathrm{ml} \mathrm{LB}$ (KNA + RIP) liquid medium with the sterilized spearhead and cultured in a constant temperature shaker at $28{ }^{\circ} \mathrm{C} / 220 \mathrm{RPM}$ for $12 \mathrm{~h}$. The bacteria solution was poured into a $50 \mathrm{ml}$ centrifuge tube and centrifuged at $5000 \mathrm{RPM}$ for $10 \mathrm{~min}$ to collect the bacteria. $10 \mathrm{ml}$ induction medium (it includes $10 \mathrm{mM} \mathrm{MgCl}, 10 \mathrm{mM}$ MES, $200 \mathrm{mM}$ acetylsyringone and $\mathrm{PH}$ is 5.5) was added to each centrifuge tube to resuspend the bacteria, and the bacteria were induced at $60 \mathrm{RPM}$ at room temperature for $4 \mathrm{~h}$ on a small shaking table. The OD600 value was adjusted between $0.8-1.2$ by fresh induction medium. The fungus liquid was slowly and uniformly injected into the pear of about 35 days with a syringe needle. The injected pear fruit was incubated at $22^{\circ} \mathrm{C}$ in the dark for $24 \mathrm{~h}$, and then cultured at $22^{\circ} \mathrm{C}$ for $16 \mathrm{~h}$ under light for $8 \mathrm{~h}$ and then put it in darkness for 7-8 days. The pear was longitudinally cut and dyed, and the lignin content was determined.
(A)

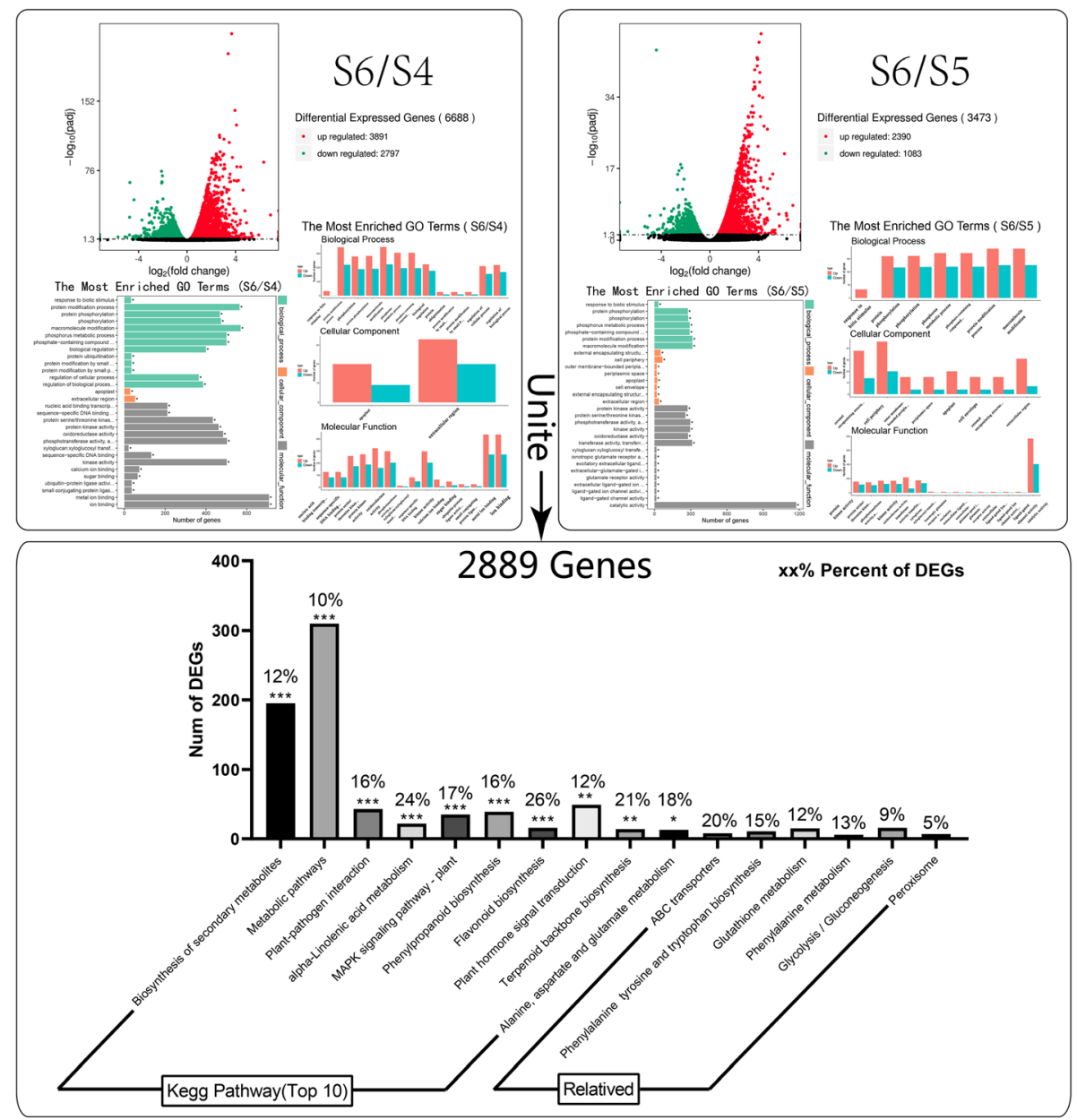

(C)

Fig. 2 Transcriptome differential analysis. (A) Differential analysis of S5 and S4 on the transcriptome, including scatter plots during DEGs screening and GO functional enrichment plots of DEGs. (B) Differential analysis of S6 and S4 on the transcriptome, including scatter plots during DEGs screening and GO functional enrichment plots of DEGs. (C) KEGG enrichment map based on these intersecting DEGs contains the proportion and number of DEGs in each biological pathways [34-36] 


\section{Statistical analysis}

All experiments were repeated three times, in a completely random design. The results were analyzed invariance by using the SAS/STAT statistical analysis package (version 6.12, SAS Institute, Cary, NC, USA). The data in the figures means \pm SDs and different letters indicated significant differences $(p<0.05)$.

\section{Result}

\section{Morphological indices and lignin content}

Callus dealt with $0.5 \%$ calcium nitrate showed slight browning comparing to calli treated with CK and $0.1 \%$. The callus treated with $\mathrm{CK}$ and calcium nitrate at $0.1 \%$ concentration grew faster, and the volume increased rapidly, while callus treated by calcium nitrate at $0.5 \%$ grew slower. Callus treated with $0.1 \%$ calcium nitrate had a better phenotype than another two treatments on the 10th day, the callus had a loose structure, wet surface, good growth condition and almost no scar. Compared with $\mathrm{CK}$ and $0.1 \%$ calcium nitrate, the callus treated with
$0.5 \%$ showed poor growth state, serious browning, and slower volume growth rate (Fig. 1-A).

Compared with the control group, the $\mathrm{Ca}$ content in the tissue increased significantly with the treatment of $\mathrm{Ca}\left(\mathrm{NO}_{3}\right)_{2}$ in each period (Fig. 1-B). In terms of lignin content, there was no significant difference between the control group and the treatment group in the 5th day. However, there was a significant difference in the 10th day and the 15th day. Compared with S4, the lignin content of S5 decreased while that of S6 increased significantly. Compared with S7, the lignin content of S8 significantly reduced while that of $\mathrm{S} 9$ increased slightly (Fig. 1-C). As a result, $0.5 \% \mathrm{Ca}\left(\mathrm{NO}_{3}\right)_{2}$ treatment significantly affects the surface color of callus, and it increased the lignin content of pears' pulp.

\section{Transcriptome analysis}

In order to find the changes in the metabolic signals and regulatory network of pear callus after calcium nitrate treatment, three samples on the tenth day were selected for preferable analysis (control [S4],

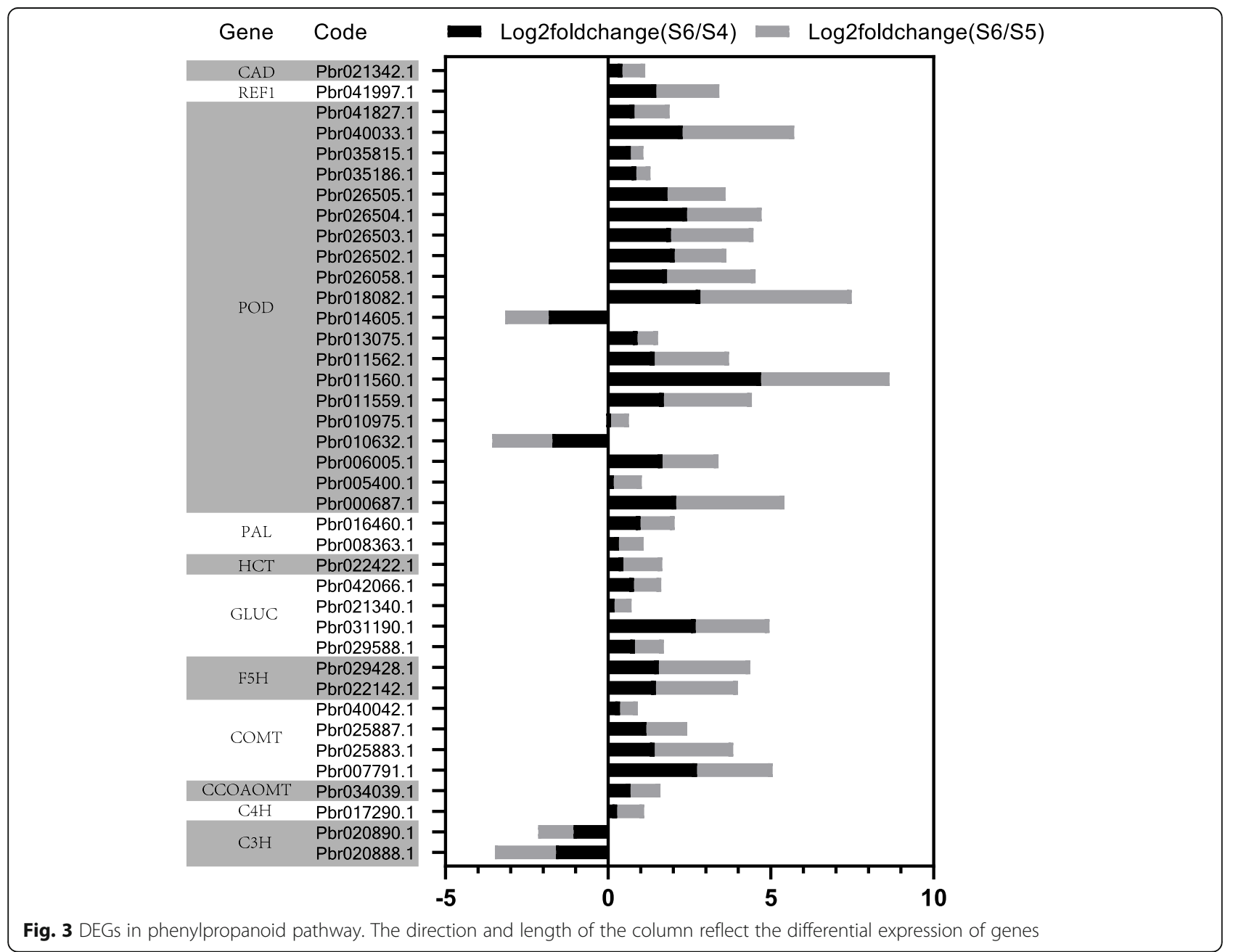


0.1\% Calcium nitrate treatment [S5], 0.5\% calcium nitrate treatment [S6]) because of the significant differences with lignin content among them. After comparative analysis between $\mathrm{S} 6$ and S4, a total of 6688 DEGs were identified, including 3891 upregulated and 2797 down-regulated (Fig. 2-A). After comparative analysis between S6 and S5, 3473 DEGs were found, in which the number of up-regulated was 2390, and the down-regulated was 1083 (Fig. 2-B). The intersection of 2889 DEGs between S6/S4 and S6/S5 was obtained.

In order to better classify functional clusters of DEGs, we analyzed the intersection obtained from S6/S4 and S6/S5 by using the online KEGG pathway database (Fig. 2-C). A total of 16 KEGG metabolic pathways were significantly enriched, these metabolic pathways mainly include metabolic pathways, biosynthesis of secondary metabolites, signal transduction of plant hormones, the interaction of plant pathogens, biosynthesis of phenylpropyl, MAPK signaling pathway, metabolism of linolenic acid and biosynthesis of flavonoids. Among them, the metabolic pathways and the biosynthesis of secondary metabolites were participated in the largest number of DEGs, respectively accounting for 10 and $12 \%$ of the total number of genes in the two metabolic pathways. In addition, several related metabolic pathways have been identified, including glycolysis, ABC transport, glutathione metabolism, biosynthesis of phenylpropanoid and tryptophan.

Also, three samples on the fifth day were analyzed, 7205 DEGs were obtained by the intersection of $\mathrm{S} 3 / \mathrm{S} 2$ and $\mathrm{S} 3 / \mathrm{S} 1$. The time dimensions were combined and took the intersection of 5 day and 10 day DEGs to obtain 1473 genes (Table S6). Venn diagrams of DEGs were drawn by R script (Fig. S1).

\section{DEGs in the shikimate pathway and phenylpropanoid pathway}

Lignin synthesis is a complex process involving multiple pathways. Related studies have shown that the phenylpropanoid pathway is generally considered to be one of the main pathways for lignin synthesis. PAL, CAD, C4H, $\mathrm{C} 3 \mathrm{H}$ and COMT are the key enzymes involved in lignin synthesis in the phenylpropanoid pathway. A total of 11 phenylpropanoid pathway DEGs were selected according to the sequencing results (Fig. 3). Among them, most of the DEGs were up-regulated. Only two $\mathrm{C} 3 \mathrm{H}$ encoding genes Pbr020890.1 and Pbr020888.1, and two POD encoding genes Pbr014605.1 and Pbr010632.1 showed

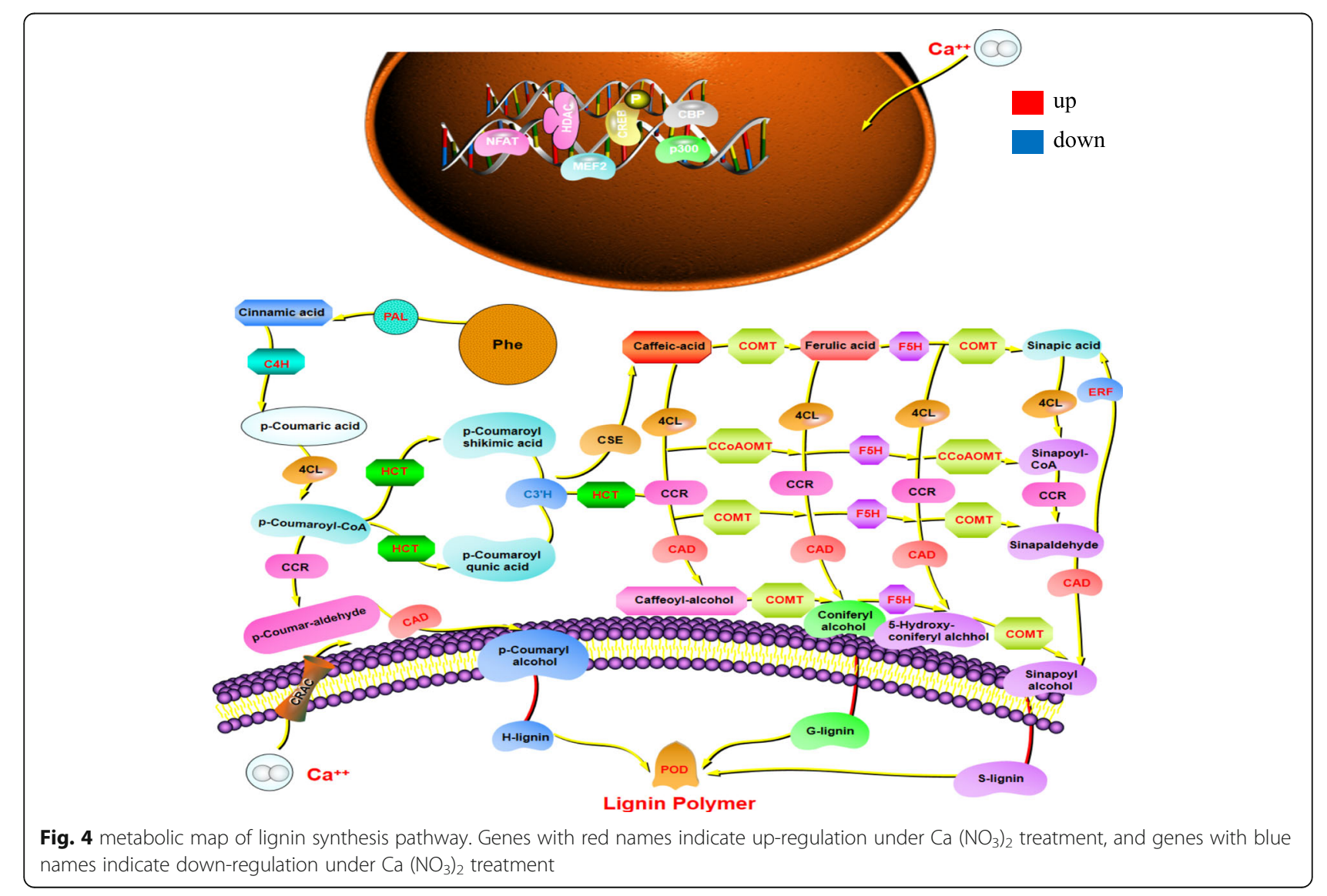


negative regulation. Among all the DEGs, POD encoding genes Pbr011560.1 and PbrO1808.1, F5H encoding genes Pbr029428.1 and Pbr022142.1, and COMT encoding genes Pbr007791.1 had obvious and significant differences. Shown as the phenylpropanoid metabolic pathway (Fig. 4), genes with red names indicated up-regulation under $\mathrm{Ca}\left(\mathrm{NO}_{3}\right)_{2}$ treatment, and genes with blue names indicated down-regulation. According to the comprehensive analysis, there were some significant changes in phenylpropanoid metabolism pathway, in which the key enzymes involved in lignin synthesis were mainly positively regulated.

DAHPS, TRPS, SDH, ASP and ADT are the key enzymes involved in lignin biosynthesis in the shikimate pathway. A total of 9 DEGs were selected according to the sequencing results. Among them, all genes of the shikimate pathway were positive regulation. However, as important transporters in secondary metabolism, $A B C$ transporters are mostly down-regulated (Fig. 5).

\section{Screening of differentially expressed calmodulin genes} Multiple studies have shown that $\mathrm{Ca}^{2+}$ can increase the strength of the cell wall and maintain its integrity. Calcium signals generated by changes in intracellular $\mathrm{Ca}^{2+}$ concentration are mainly signal transduced by calcium target proteins. There are three main types of calcium target proteins in plants: calmodulin/ calmodulin-like protein (CAM/CML), calciumdependent protein kinase (CDPK), and calmodulin phosphatase $\mathrm{B}$ protein $(\mathrm{CBL})$.

In order to study the expression trend of calciumrelated genes in pear callus after treatment, we used the software Pheatmap to cluster the selected calciumrelated genes, and the results showed that the three main calcium target proteins were all involved in the response mode after treatment with calcium callus for 10 days (Fig. 6). The correspondence between the gene name and coding can be found in Table S2. Among them, the number of CMLs involved was the largest. Most CML genes were firstly none-regulated at the S5 level and then significantly up-regulated at the S6 level. The number of CAM DEGs and CDPK DEGs was similar, and most of them were significantly up-regulated at S6, while the number of CBL was only 1 , which was also significantly up-regulated at S6 (Fig. 6-A, B, C, D). In addition, we found a large number of up-regulated transcription factors, such as WRKY, MYB, MYC, and DELLA, which are thought to be involved in the regulation of lignin synthesis (Fig. 6-E). This suggests that calcium increases the expression level of $\mathrm{Ca}^{2+}$ sensors, suggesting that calcium nitrate treatment does induce calcium signal transduction and promote secondary metabolic pathways as a whole. This is consistent with previous studies.

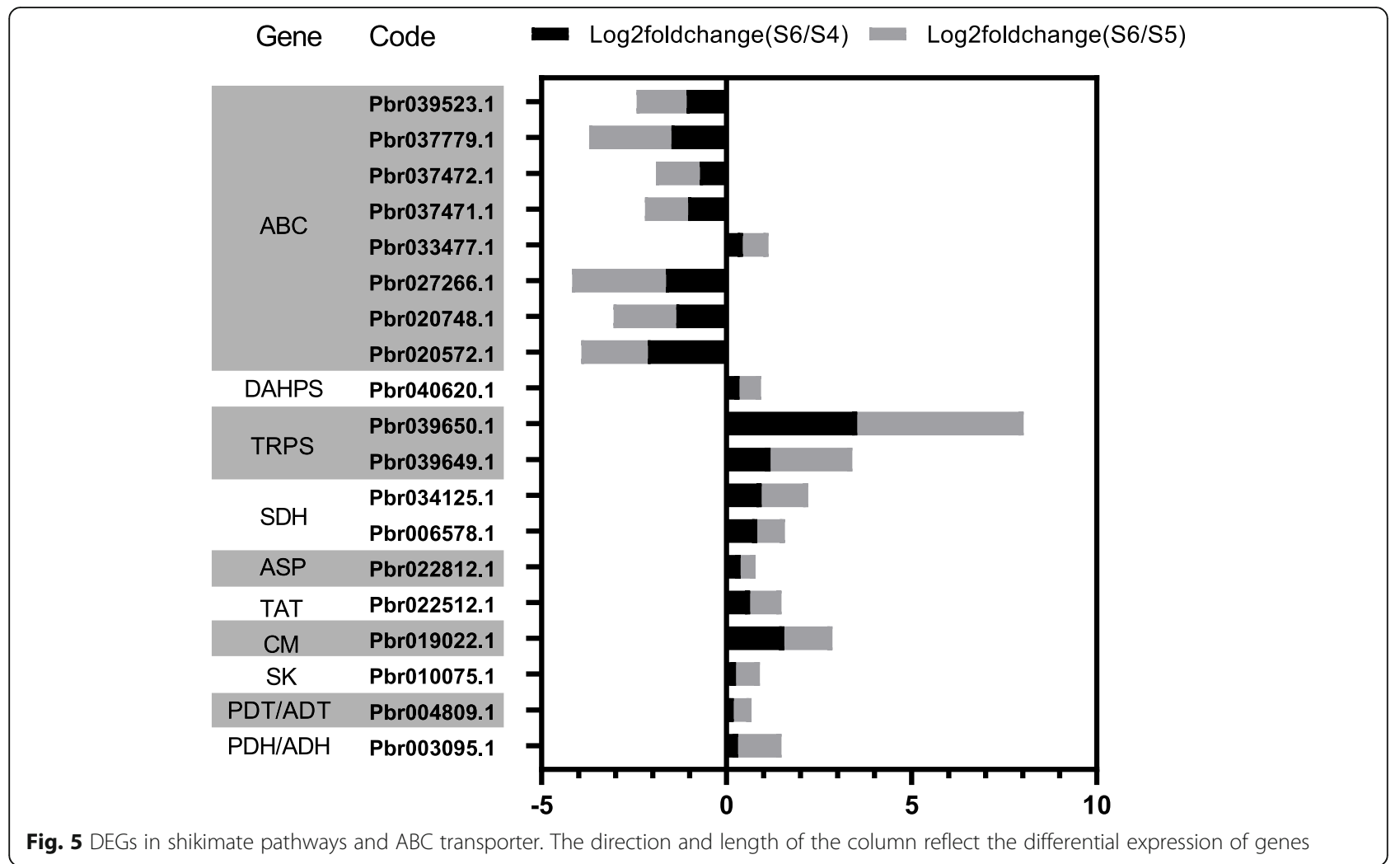




\section{PbCMLs}

(A)

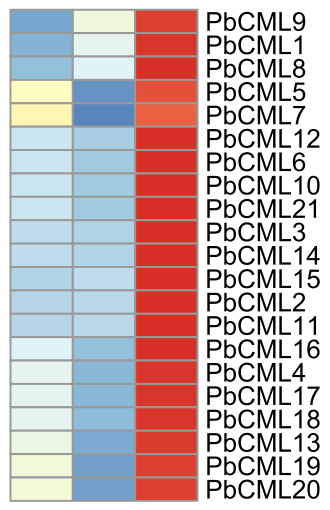

PbCAMs

(B)

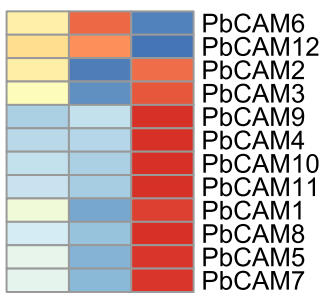

\section{$\mathrm{PbCBL} / \mathrm{CIPKs}$}

(C)

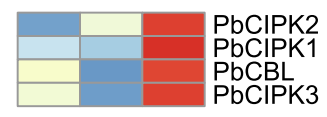

PbCDPKs

(D)

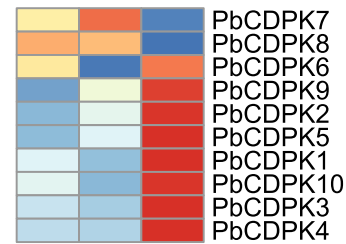

S4 S5 S6

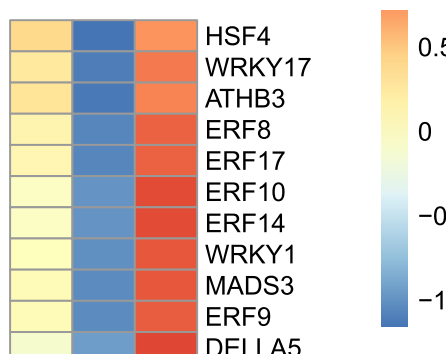

0.5

0

$-0.5$

DELLA5

WRKY2

MYC1

ERF16

WRKY18

ERF11

MYB

WRKY6

ERF4

WRKY5

WRKY9

WRKY7

HSF3

WRKY16

WRKY4

MADS2

WRKY13

DELLA7

WRKY8

ERF13

MYC4

HSF1

MYC7

HSF2

WRKY14

ERF1

ERF12

WRKY10

WRKY3

ERF3

ERF5

HSF5

WRKY19

ERF2

ERF7

WRKY12

WRKY21

DELLA3

ERF15

DELLA4

HSF6

WRKY11

WRKY20

MADS1

MYC5

\section{S4 S5 S6}

Fig. 6 Heatmap of calcium-related differential expressed genes in transcriptome. The three columns represent the gene expression at S4, S5 and $\mathrm{S} 6$ respectively. (A) The expression pattern of CML gene family in callus among DEGs. (B) The expression pattern of CAM gene family in callus among DEGs. (C) The expression pattern of CBL/CIPK gene family in callus among DEGs. (D) The expression pattern of CDPK gene family in callus among DEGs. (E) The expression patterns of transcription factors in different genes in callus

Real-time quantitative PCR verification of DEGs

In order to further verify the reliability of transcriptome sequencing expression profile data when treated with calcium nitrate, we selected 15 DEGs in the phenylpropanoid pathway and $18 \mathrm{PbCMLs}$, and verified the results of transcriptome sequencing by real-time fluorescence quantitative PCR. The results showed that the expression pattern of phenylpropanoid pathway DEGs was basically consistent with the transcriptome (Table S4). However, the PCR results of $\mathrm{PbC} 3 \mathrm{H} 1$ showed that the relative expression of $\mathrm{S} 4$ treatment was higher than transcriptome data (Fig. 7). The expression pattern of 


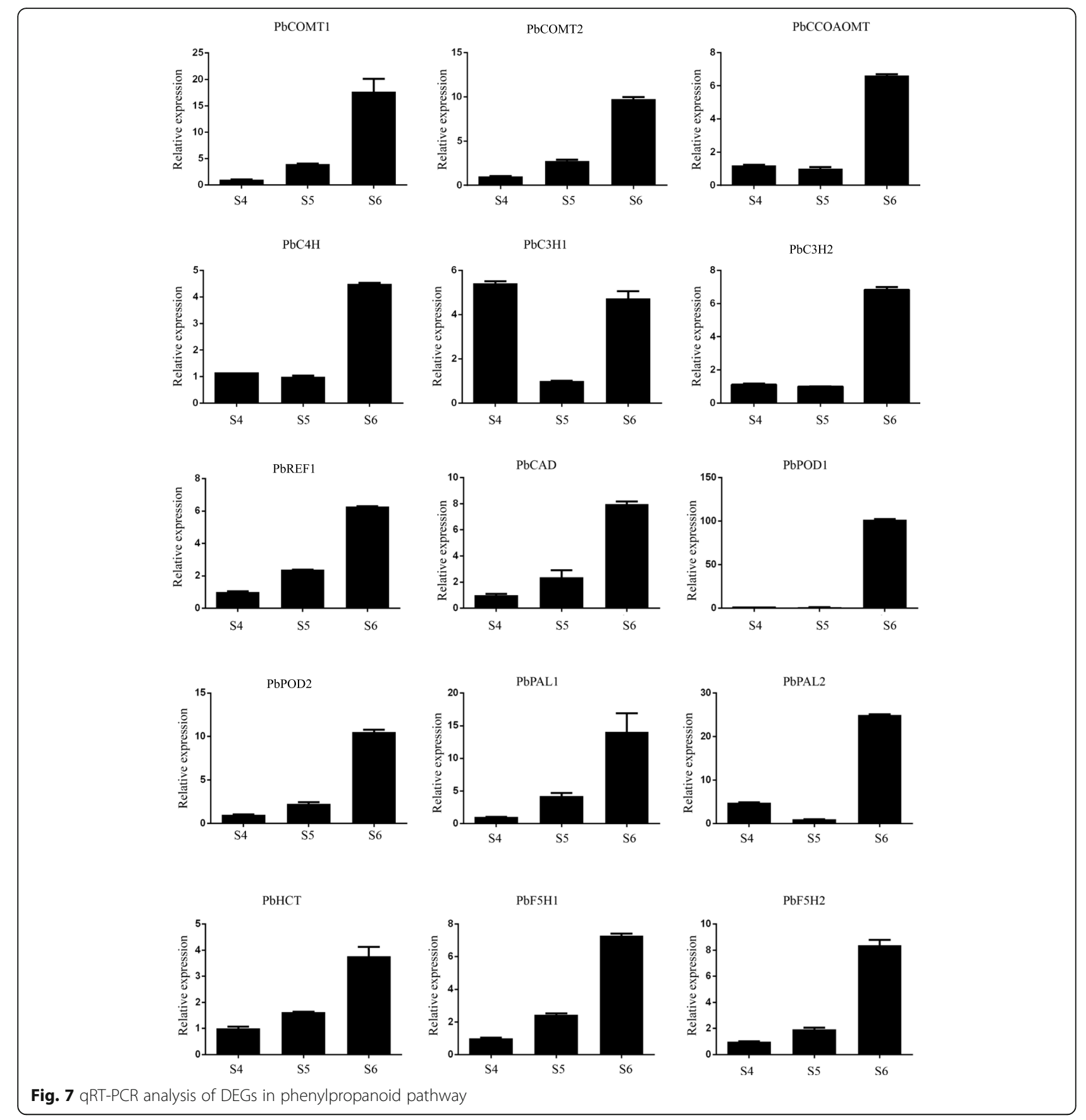

$\mathrm{PbCMLs}$ was consistent with the data in transcriptome. In addition, The relative expression of all $P b C M L s$ were the highest in S6 (Fig. 8).

\section{Manipulating PbCML3 expression increases stone cells in pear}

'Dangshansuli' pear fruit stone cells begin to differentiate around 20 days after flowering, and peak at 40 to 50 days after flowering. The relative expression level of $\mathrm{PbCML3}$ in the fruit first increased and then decreased and reached its peak at 45 days after flowering, which was consistent with the expression rules of pear fruit stone cells (Fig. 9-A). Combining transcriptome data, it was further speculated that $P b C M L 3$ had a certain regulatory effect on lignin and stone cell synthesis. $P b C M L 3$ was overexpressed in pear fruits 35 days after blooming, one side of the fruit was injected with 35S-GFP-PbCML3 and the other side served as a control. After 10 days, the fruits were cut into slices and stained with phloroglucinol and hydrochloric acid (Fig. S2). The content of stone cells in the overexpressed $\mathrm{PbCML3}$ side was higher than that in the uninjected side (Fig. 9-B). By measuring the 


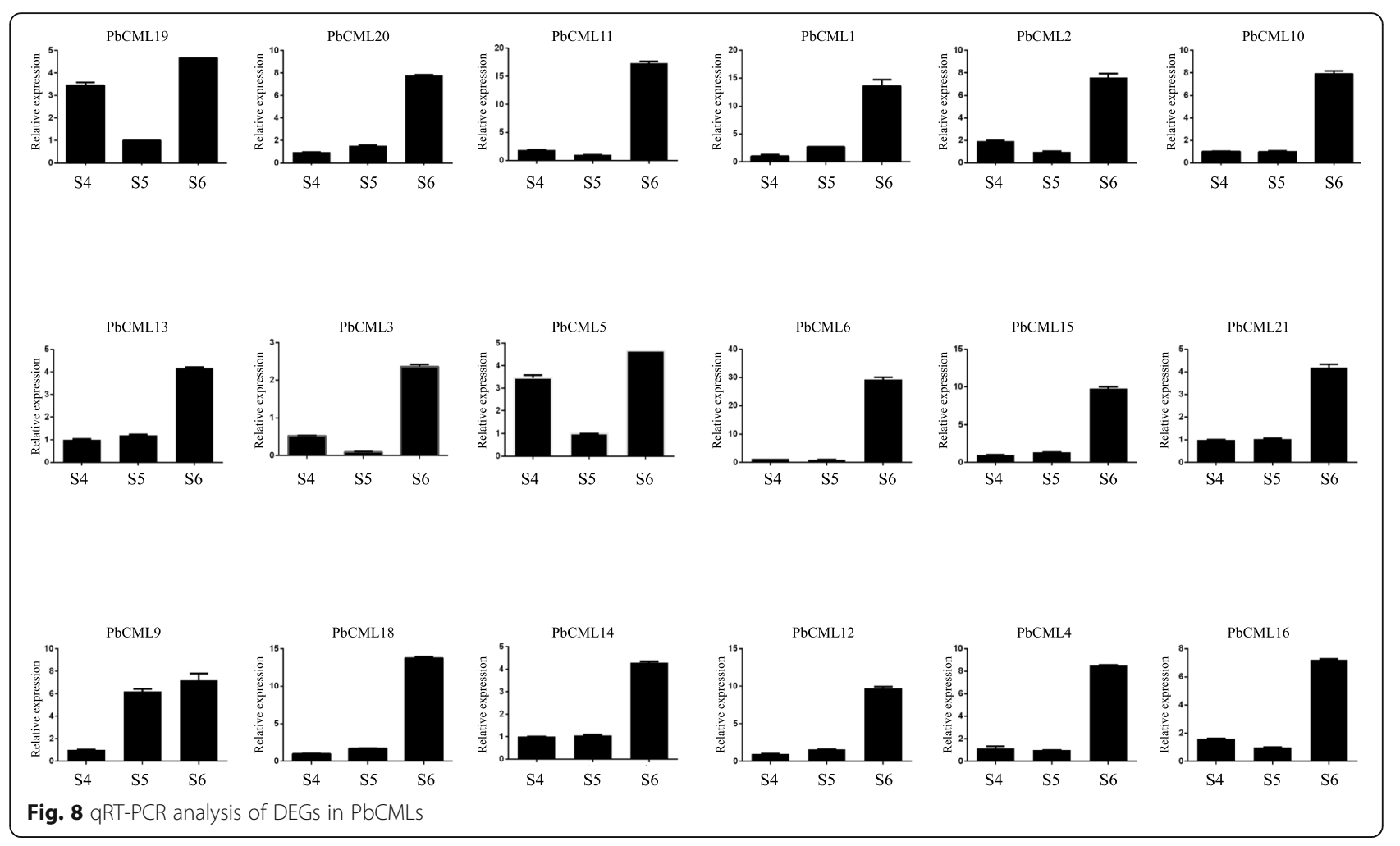

content of lignin in fruits in corresponding areas, it was found that the content of lignin in the overexpression vector region injected was higher than that in the region not injected, which increased by about $30.1 \%$, reaching a significant difference. The relative expression of overexpression vector $P b C M L 3$ in the fruit region was higher than that in the uninjected region, and increased by $574.1 \%$. At the same time, lignin-related DEGs were upregulated in the injection area (Fig. 9-D).

\section{$\mathrm{PbCML3}$ localizes in plasma membrane}

To clarify the function of the PbCML3 signal transporter, we analyzed the subcellular localization of PbCML3. The distribution of PbCML3 in the cell was determined by the method of instantaneous transformation of agrobacterium. After transient transformation into tobacco, 35S-GFP-PbCML3 fusion protein produced green fluorescence on the cell membrane, whereas the control displayed fluorescence in the cytosol and nuclei in the cells, indicating that PbCML3 was located on the cell membrane (Fig. 10).

\section{Discussion}

Exogenous $0.5 \%$ calcium nitrate promotes the process of secondary metabolism

$\mathrm{Ca}^{2+}$ has long been regarded as the second messenger of signal transduction [37], which plays an important physiological role in regulating plant cell elongation, cell membrane integrity, reactive oxygen metabolism [38]. In addition, it can affect plant photosynthesis, fruit quality, stem mechanical strength and stress resistance [11, 39, 40]. Application of $0.5 \% \mathrm{CaCl}_{2}$ can inhibit the formation of stone cells [41]. However, different types of exogenous calcium may have different effects on lignin, treatment with $2 \%$ nano- $\mathrm{CaCO}_{3}$ was found to have effect on the mechanical strength of P.lactiflora inflorescence stems, with an observed increase of $30.73 \%$ [42]. In the present study, the treatment with $0.1 \% \mathrm{Ca}\left(\mathrm{NO}_{3}\right)_{2}$ was found to have an influence on the lignin content of pear callus, but $0.5 \% \mathrm{Ca}\left(\mathrm{NO}_{3}\right)_{2}$ was found to have an effect on the lignin content, with an observed increase on 10th day. Thus, the influence of lignin synthesis by exogenous calcium may have a potential relationship with the concentration on treatment. In the transcriptome, these 2889 DEGs were enriched into 16 KEGG metabolic pathways, including biosynthesis of secondary metabolites, phenylpropanoid biosynthesis, flavonoids biosynthesis, and signal transduction of plant hormones, etc. According to related research proof, phenylpropanoid metabolic pathway is one of the main path of lignin synthesis [5], all kinds of aromatic amino acids in this way will be formed by the chemical effect such as deamidation coumaric acid, coenzyme $\mathrm{A}$, and then enter the flavonoids secondary metabolites biosynthesis pathway generated, thus forming lignin monomer and other secondary metabolites. The sequencing results were 
(A)

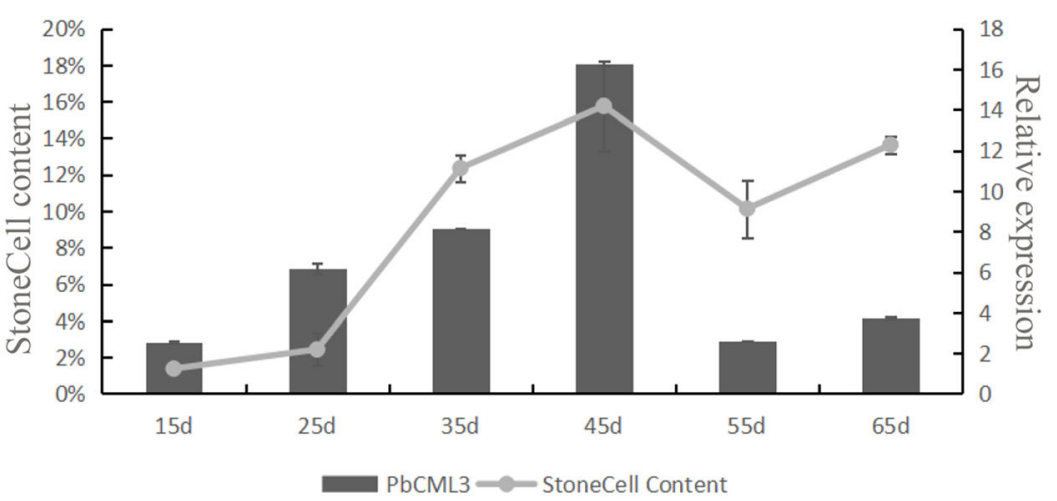

(B)

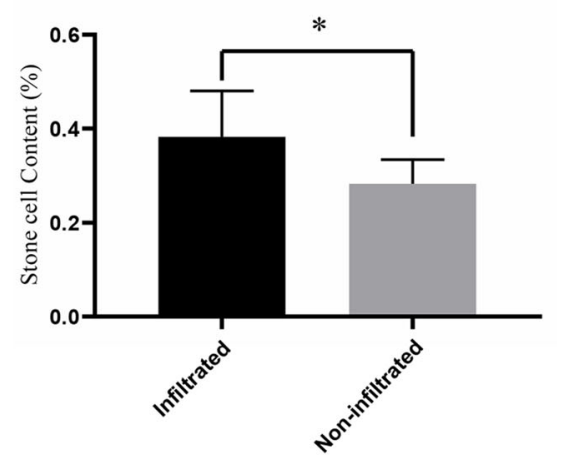

(D)

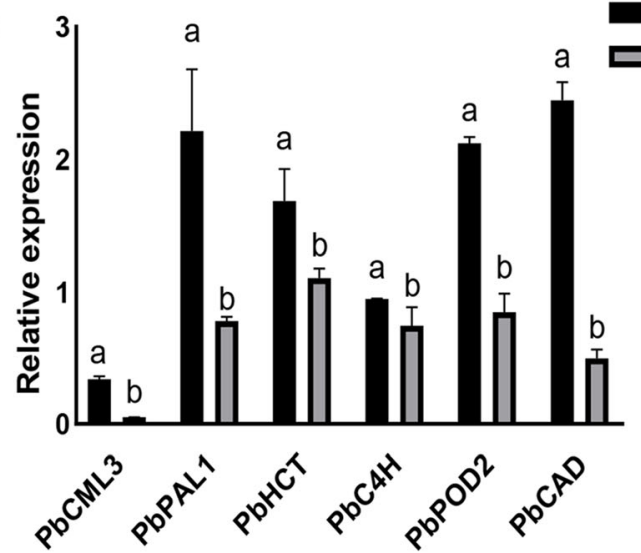

(C)

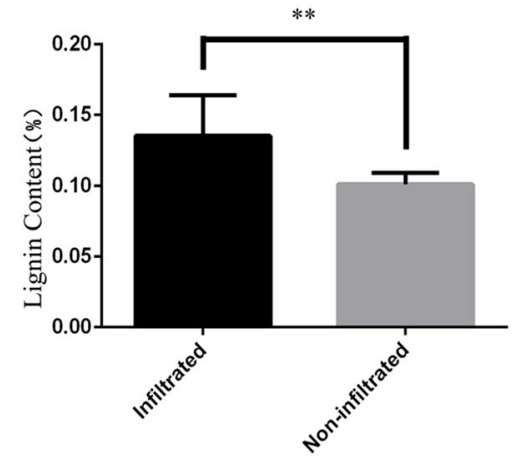

Infiltrated

• Non-infiltrated

Fig. 9 Association between pear stone cells and PbCML3. (A) Dynamic changes of stone cell content and PbCML3 in pear fruit development. (B) The content of stone cell in two sides. (C) The content of lignin in two sides. (D) Expression patterns of DEGs at injection site and non-injection site

screened for genes related to phenylpropanoid pathway, most of which showed positive regulation. These results indicate that exogenous calcium nitrate can regulate phenylpropanoid pathway, and affect lignin synthesis. Moreover, As the upstream pathway of the phenylpropanoid for the synthesis of lignin, the shikimate pathway has also undergone a large number of gene upregulations. For example, arogenate dehydratase (ADT), regarded as a link between phenylalanine biosynthesis and lignin biosynthesis
[43], is found in DEGs. Thus the regulation of exogenous calcium is not limited to phenylpropanoid pathway and lignin synthesis, but the entire secondary metabolism [44]. It had been demonstrated that exogenous calcium chloride treatment could increase the hardness of peony stems by enhancing lignin synthesis [9]. Also, the pear callus treated with calcium nitrate became brown and dull due to the more accumulation of lignin and other secondary metabolites. 

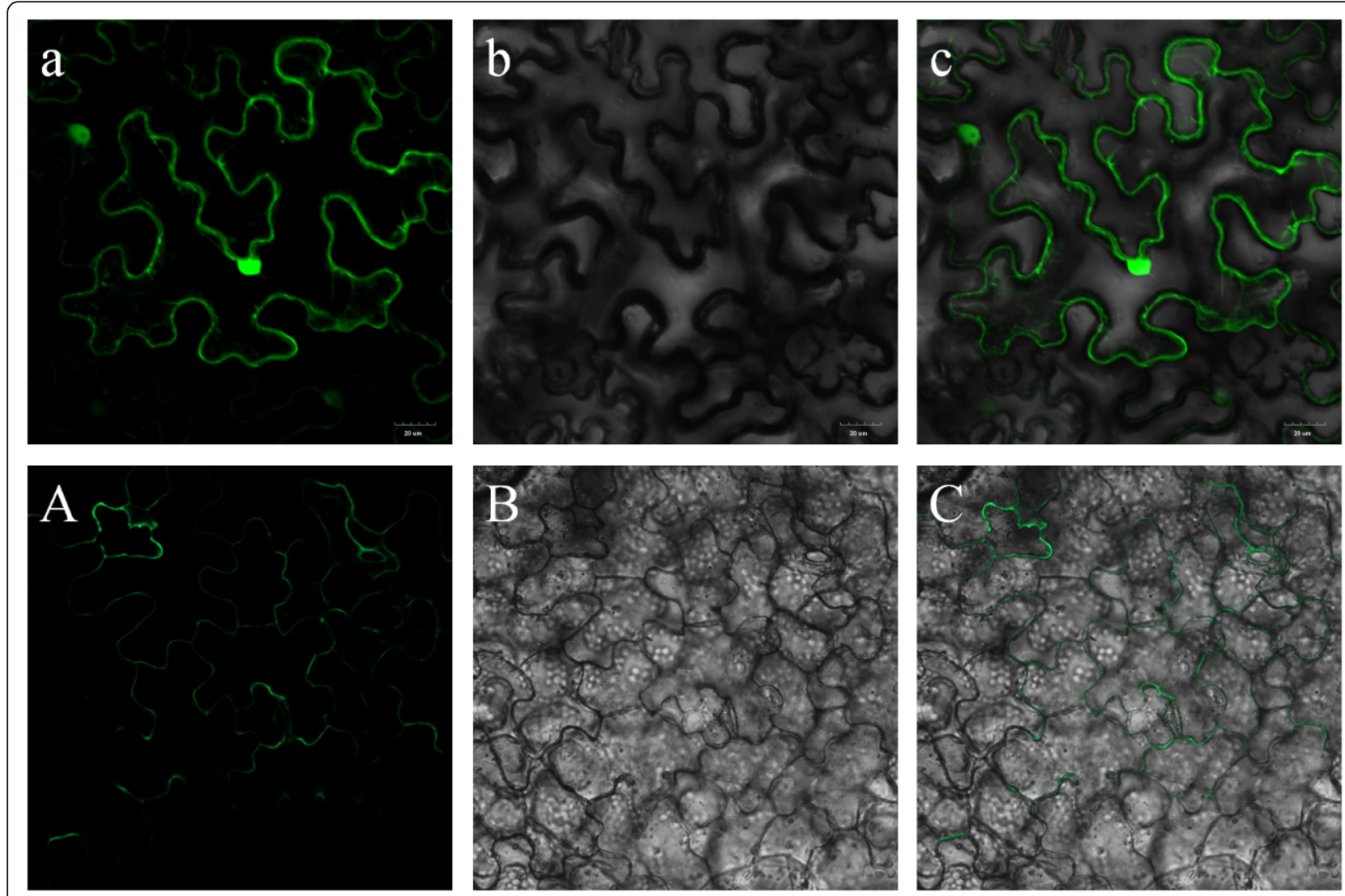

Fig. 10 Subcellular localization of PbCML3 in tobacco mesophyll protoplasts. (A) Localization of 35S-GFP-PbCML3 fusion protein in tobacco mesophyll protoplasts. (B) FM 4-64 fluorescence (membrane marker) detected in the plasma membrane. (C) Merge of A and B

The regulatory network from calcium to stone cells in pear

Lignin is the major component of the secondary cell walls and provides compression strength to the walls [3]. In pear, the accumulation of lignin is the key to the formation of stone cells [2]. In this study, we identified a lignin biosynthesis pathway that can enrich 9 DEGs (PAL, C4H, CAD, C3H, HCT, COMT, CCoAOMT, F5H and POD). Transcription factors regulating lignin synthesis, such as WRKY, MYB and DELLA, are also differentially expressed in this study. On previous studies, WRKY36 and WRKY102 are associated with repression of rice lignification [45], transcription factors MYB58 and MYB63 function in the control of lignin biosynthetic genes [46], the DELLA protein regulates the xylem fiber differentiation of Arabidopsis thaliana by binding to KNAT1 [47], ERF transcription factor named Ii049 positively regulates lignan biosynthesis in isatis indigotica through activating salicylic acid signaling and lignin pathway genes [48]. Moreover, RNA-seq identified five DEGs (CAM, CML, CIPK, CBL and CDPK) involved in calcium signal transduction, and they were up-regulated after $0.5 \% \mathrm{Ca}\left(\mathrm{NO}_{3}\right)_{2}$ treatment. Furthermore, members of MYB families played roles as CAM-binding transcription factors [49]. Related research speculate that $\mathrm{Ca}^{2+}$ concentration increase can improve peony stem mechanical strength. Flower stem cell induced by calcium signal transduction, and it upregulate the NAC and MYB family, so as to promote secondary cell wall thickening [9]. Combined with our transcriptome data, this hypothesis is further proposed. Exogenous calcium regulates lignin by promoting calcium signal transduction and upregulating transcription factors, thus increasing lignin and stone cells in fruits. $A B C$ transporters $(\mathrm{ABCF})$, as potential monolignol transporter involved in lignin biosynthesis $[50,51]$, were found to be downregulated in this processing and it may be caused by a certain degree of cell death during lignin synthesis. In the present study, a large number of secondary metabolic pathway genes and transcription factors of DEGs provide a network of exogenous calcium that causes metabolic pathway changes and leads to the accumulation of lignin in pear callus (Fig. 11).

\section{Overexpression of $P b C M L 3$ promotes stone cells}

The expression level of $P b C M L 3$ at different developmental stages of pear fruit has demonstrated that $P b C M L 3$ is expressed highest on 45th day (Fig. 9-A). 


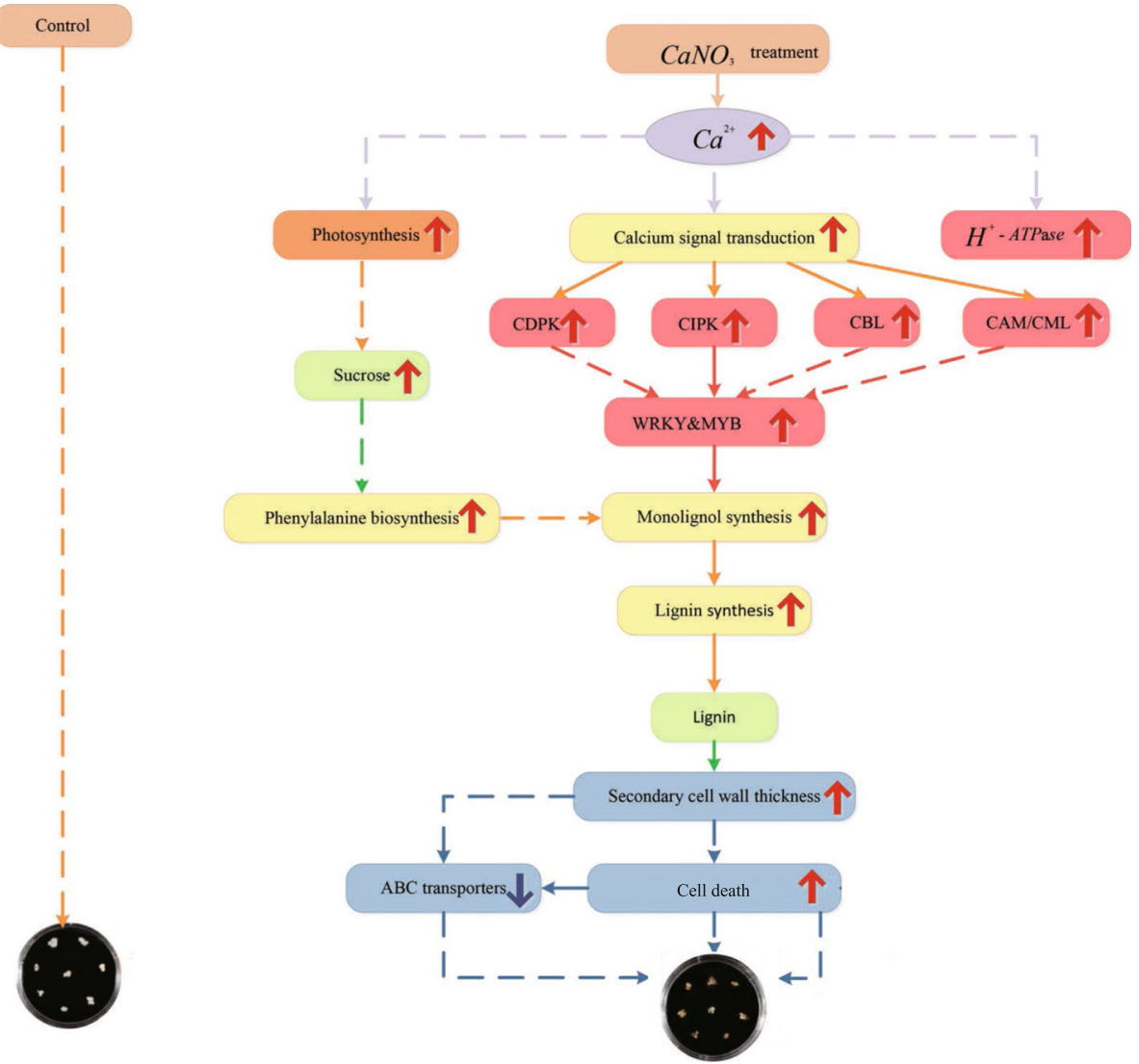

Fig. 11 Proposed pathway for calcium-mediated enhancement of the lignin of pear callus

Moreover, the expression pattern of $P b C M L 3$ was consistent with the content of stone cells. It has been demonstrated that Lignin deposition is an important factor, which leads to the hardening of the cell wall of stone cells [2]. In our research, the stone cell and lignin content in $\mathrm{PbCML3}$ overexpression side was much higer than that of other side (Fig. 9-B, C). Thus, overexpression of $P b C M L 3$ might cause changes in lignin pathway genes. Many previous reports had found that CML plays an important role in plant growth and development and stress, such as regulating the morphology and division of plant cells $[26,45]$ and responsing to salt, drought and low temperature stress [29]. AtCML9 was found to promote plant innate immunity through flagellin-dependent signaling pathways [28]. The anti-stress function of plants is closely related to the synthesis of lignin [52]. The author hypothesized that $P b C M L 3$ indirectly regulates lignin pathway genes. Furthermore, in the results of our qRT-PCR, the expression of important lignin synthesis DEGs (PbPAL1, PbHCT, PbC4H, PbPOD2 and $P b C A D)$ were found to upregulate on the $P b C M L 3$ overexpressed side in fruit (Fig. 9-D). Those results prove that the CML gene can cause lignin accumulation during fruit development, which might be related to the regulation of stone cells content. Our research showed that $P b C M L 3$ could promote lignin metabolism and thus stone cells accumulation. And then the specific regulation mechanism of CML on lignin content needs further study.

\section{Abbreviations}

2,4-D: Auxin; AGAR: Agarose; ASP: Aspartate aminotransferase; C3H: Pcoumarate 3-hydroxylase; C4H: Cinnamate-4-hydroxylase; CAD: Innamylalcohol dehydrogenase; $\mathrm{CaCl}_{2}$ : Calcium chloride; $\mathrm{CaCO}_{3}$ : $\mathrm{Calcium}$ carbonate; $\mathrm{Ca}\left(\mathrm{NO}_{3}\right)_{2}$ : Calcium nitrate; CAM: Calmodulin protein; $\mathrm{CBL}$ : Calmodulin phosphatase B protein; CCOMT: Caffeoyl-CoA-3-O-methyl transferase; CCR: Cinnamoyl-CoA reductase; CDPK: Calcium-dependent protein kinase; CIPK: Calcineurin B-like interacting protein kinase; CML: Calmodulin-like protein; CSE: Caffeoy shikimate esterase; DAF: Days after full bloom; DAHP S: 3-deoxy-D-arabino-heptulosonate-7-phosphate-synthase:

DEGs: Differentially expressed genes; F5H: Ferulate 5-hydroxylase:

FPKM: Reads per kilobase of exon model per million mapped reads; GFP: Green fluorescent protein; GO: Gene ontology; HCT: Hydroxycinnamoyl transferase; KEGG: Kyoto encyclopedia of genes and genomes; KNA: Kanamycin; LAC: Laccase; LB: Luria-Bertani medium; NAA: 1Naphthaleneacetic acid; NADPH: Nicotinamide adenine dinucleotide phosphate; NCBI: National Center of Biotechnology Information; PAL: Phenylalanine ammonia-lyase; PDT: Prephenate dehydratase; POD: Peroxidase; RPM: Revolutions per minute; qRT-PCR: Quantitative realtime polymerase chain reaction; SDH: Shikimate dehydrogenase: 
TDZ: Thidiazuron; RIP: Rifampicin; TRPS: Tryptophan--tRNA ligase; VC: Vitamin

\section{Supplementary Information}

The online version contains supplementary material available at https://doi. org/10.1186/s12864-021-08161-5.

Additional file 1. Table S1 Sequence of qRT-PCR primers. The "name" column of the table indicates the name of the gene in the manuscript, and the "Coding" column of the table indicates the serial number of the gene in pyrus genome

Additional file 2. Table S2 Gene numbers in heatmap. The serial numbers of all genes in the heatmap of Fig. 6. (Table S2a) Corresponding names of calcium-related genes. (Table S2b) Corresponding names of transcription factors

Additional file 3. Table S3 The number of transcriptome data uploaded to NCBI. For S1 S6, each sample has three biological replicates, which are recorded with different SRR numbers. Transcriptome files are fastq files for paired sequencing

Additional file 4. Table S4 The expression matrix of transcriptome DEGs and raw data of qRT-PCR. (Table S4a) Transcriptome expression of related genes. The expression matrix of transcripts mentioned in the manuscript was provided, the unit of value is fpkm. (Table S4b) The original data of qRT-PCR. (Table S4c) Correlation between R-Seq and qRT-PCR in CMLs. The correlation of each CML DEGs were calculated with S4 S6, and the values are all greater than 0.8

Additional file 5. Table S5 The fpkm matrix of transcriptome DEGs Additional file 6. Table S6 The information of DEGs intersection. Table S6. The information of DEGs intersection. The DEGs intersection information with the two periods is provided. The table includes the KEGG function, chromosome position, positive and negative chain, gene length (bp), exon length (bp), CDS length (bp), amino acid Length (bp), number of exons, average length of exons (bp) and average length of introns (bp). The transcripts labeled "Novel" are not annotated by the genome

Additional file 7. Fig. S1 The Veen diagram of DEGs. The Veen diagram is drawn by Rscript, which shows the relationship set between the DEGs of S6/S4, S6S5, S3/S1 and S3/S2

Additional file 8. Fig. S2 Pear fruit injected with PbCML3. Each fruit is divided into injected side and non-injected side and the stone cells of the fruit are stained red

\section{Acknowledgments}

We thank Yiming Shen and Xuebing Zhang (technicians of Orchard in Baoying) for managing the fruit trees.

\section{Statement}

We declare that we have obtained permission from the orchard owner in the process of collecting the fruits.

We declare that the plant material in the experiment was collected and studied in accordance with relevant institutional, national, and international guidelines and legislation.

\section{Authors' contributions}

ShuTian Tao designed the experiment and reviewed manuscript. XingYu Tao was in charge of bioinformatics analysis and image rendering. Min Liu, YaZhou Yuan and RuoNan Liu were in charge of plant material processing. KaiJie Qi, ZhiHua Xie and JianPing Bao were in charge of literature collection. ShaoLing Zhang, Katsuhiro Shiratake organized the experiment process. All authors reviewed the manuscript. All authors read and approved the final manuscript.

\section{Funding}

This work was financially supported by the National Key Research and Development Program of China (2020YFD100020), the National Natural Science Foundation of China (31672105, 31972361, and U2003121), and
Major Science and Technology Project of Corps (2017dB006), for the design of the study and the collection, analyses, and interpretation of data.

\section{Availability of data and materials}

The data of this study are available and the plant materials of this article have been frozen in the life sciences building of Nanjing Agricultural University. The transcriptome datasets supporting the conclusions of this article in the National Center for Biotechnology Information (https://www. ncbi.nlm.nih.gov/bioproject/PRJNA636000). Anyone who wants to obtain the public data in the research can contact us at taost@njau.edu.cn.

\section{Declarations}

Ethics approval and consent to participate

Not applicable.

\section{Consent for publication}

The authors give consent to the publication of the article.

\section{Competing interests}

The authors declare that they have no conflict of interest.

\section{Author details}

${ }^{1}$ State Key Laboratory of Crop Genetics and Germplasm Enhancement, Nanjing Agricultural University, Nanjing 210095, China. ${ }^{2}$ College of Plant Science, Tarim University, Ala'er, China. 'Laboratory of Horticultural Science, Nagoya University, Nagoya, Japan.

Received: 12 May 2021 Accepted: 22 October 2021

Published online: 17 November 2021

\section{References}

1. Smith WW. The course of stone cell formation in pear fruits. Plant Physiol. 1935;10(4):587-611. https://doi.org/10.1104/pp.10.4.587

2. Tao ST, Khanizadeh S, Zhang H, Zhang SL. Anatomy, ultrastructure and lignin distribution of stone cells in two Pyrus species. Plant Sci. 2009;176(3): 413-9. https://doi.org/10.1016/j.plantsci.2008.12.011.

3. Wainhouse D, Cross DJ, Howell RS. The role of lignin as a defence against the spruce bark beetle Dendroctonus micans: effect on larvae and adults. Oecologia. 1990;85(2):257-65. https://doi.org/10.1007/BF00319411.

4. Cai YP, Li GQ, Nie JQ, Lin Y, Nie F, Zhang JY, et al. Study of the structure and biosynthetic pathway of lignin in stone cells of pear. Sci Hortic. 2010; 125(3):374-9. https://doi.org/10.1016/j.scienta.2010.04.029.

5. Zhao Q. Lignification: Flexibility, Biosynthesis and Regulation. Trends Plant Sci. 2016;21(8):713-21. https://doi.org/10.1016/j.tplants.2016.04.006.

6. Lan W, Lu F, Regner M, Zhu Y, Rencoret J, Ralph SA, et al. Tricin, a flavonoid monomer in monocot lignification. Plant Physiol. 2015;167(4):1284-95. https://doi.org/10.1104/pp.114.253757.

7. Lee $\mathrm{CH}$, Nam MK. Enhancement of stem firmness in standard Chrysanthemum 'Baekma' by foliar spray of liquid calcium compounds. Korean J Hortic Sci Technol. 2011;29(4):298-305.

8. Xu Y, Li X, Lin J, Wang Z, Yang Q, Chang Y. Transcriptome sequencing and analysis of major genes involved in calcium signaling pathways in pear plants (Pyrus calleryana Decne.). BMC Genomics. 2015;16(1):738. https://doi. org/10.1186/s12864-015-1887-4.

9. Zhao D, Tang Y, Xia X, Sun J, Meng J, Shang J, et al. Integration of Transcriptome, Proteome, and Metabolome Provides Insights into How Calcium Enhances the Mechanical Strength of Herbaceous Peony Inflorescence Stems. Cells. 2019:8(2):102. https://doi.org/10.3390/cells80201 02

10. Shams M, Etemadi N, Baninasab B, Ramin AA, Khoshgoftarmanesh AH. Effect of boron and calcium on growth and quality of 'Easy Lover' cut rose. J Plant Nutr. 2012;35(9):1303-13. https://doi.org/10.1080/01904167.2012.684123.

11. Perik RRJ, Raze D, Ferrante A, van Doorn WG. Stem bending in cut Gerbera jamesonii flowers: effects of a pulse treatment with sucrose and calcium ions. Postharvest Biol Technol. 2014;98:7-13. https://doi.org/10.1016/j.postha rvbio.2014.06.008

12. Li C, Tao J, Zhao D, You C, Ge J. Effect of calcium sprays on mechanical strength and cell wall fractions of herbaceous peony (Paeonia lactiflora pall.) inflorescence stems. Int J Mol Sci. 2012;13(4):4704-13. https://doi.org/10.33 90/ijms13044704. 
13. Wang $Y$, Zhang $X$, Wang $Y$, Yang $S$, Qu H. The changes of intracellular calcium concentration and distribution in the hard end pear (Pyrus pyrifolia cv. 'Whangkeumbae') fruit. Cell Calcium. 2018;71:15-23. https://doi.org/10.1 016/j.ceca.2017.11.002.

14. Hepler PK. Calcium: a central regulator of plant growth and development. Plant Cell. 2005;17(8):2142-55. https://doi.org/10.1105/tpc.105.032508.

15. Hepler PK, Winship LJ. Calcium at the cell wall-cytoplast interface. J Integr Plant Biol. 2010;52(2):147-60. https://doi.org/10.1111/j.1744-7909.2010.00923. $x$.

16. Arfaoui A, El Hadrami A, Adam LR, Daayf F. Pre-treatment with calcium enhanced defense-related genes' expression in the soybean's isoflavones pathway in response to Sclerotinia sclerotiorum. Physiol Mol Plant P. 2016: 93:12-21. https://doi.org/10.1016/j.pmpp.2015.11.004

17. Michailidis M, Karagiannis E, Tanou G, Karamanoli K, Lazaridou A, Matsi T, et al. Metabolomic and physico-chemical approach unravel dynamic regulation of calcium in sweet cherry fruit physiology. Plant Physiol Biochem. 2017;116:68-79. https://doi.org/10.1016/j.plaphy.2017.05.005.

18. Matschi S, Werner S, Schulze WX, Legen J, Hilger HH, Romeis T. Function of calcium-dependent protein kinase CPK28 of Arabidopsis thaliana in plant stem elongation and vascular development. Plant J. 2013;73(6):883-96. https://doi.org/10.1111/tpj.12090.

19. Yang T, Poovaiah BW. Calcium/calmodulin-mediated signal network in plants. Trends Plant Sci. 2003;8(10):505-12. https://doi.org/10.1016/j.tplants.2 003.09.004.

20. Costa A, Navazio L, Szabo I. The contribution of organelles to plant intracellular calcium signalling. J Exp Bot. 2018;69(17):4175-93. https://doi. org/10.1093/jxb/ery185.

21. La Verde V, Dominici P, Astegno A. Towards Understanding Plant Calcium Signaling through Calmodulin-Like Proteins: A Biochemical and Structural Perspective. Int J Mol Sci. 2018;19(5):1331. https://doi.org/10.3390/ijms1 9051331.

22. Sanders D, Pelloux J, Brownlee C, Harper JF. Calcium at the crossroads of signaling. Plant Cell. 2002;14(14 Suppl):S401-17. https://doi.org/10.1105/tpc. 002899.

23. Zhu X, Dunand C, Snedden W, Galaud JP. CaM and CML emergence in the green lineage. Trends Plant Sci. 2015;20(8):483-9. https://doi.org/10.1016/j. tplants.2015.05.010.

24. McCormack E, Braam J. Calmodulins and related potential calcium sensors of Arabidopsis. New Phytol. 2003;159(3):585-98. https://doi.org/10.1046/j.14 69-8137.2003.00845.x.

25. Boonburapong B, Buaboocha T. Genome-wide identification and analyses of the rice calmodulin and related potential calcium sensor proteins. BMC Plant Biol. 2007;7(1):4. https://doi.org/10.1186/1471-2229-7-4

26. Dobney S, Chiasson D, Lam P, Smith SP, Snedden WA. The calmodulinrelated calcium sensor CML42 plays a role in trichome branching. J Biol Chem. 2009;284(46):31647-57. https://doi.org/10.1074/jbc.M109.056770.

27. Lin WD, Liao YY, Yang TJ, Pan CY, Buckhout TJ, Schmidt W. Coexpressionbased clustering of Arabidopsis root genes predicts functional modules in early phosphate deficiency signaling. Plant Physiol. 2011;155(3):1383-402. https://doi.org/10.1104/pp.110.166520.

28. Leba LJ, Perochon A, Cheval C, Ranty B, Galaud JP, Aldon D. CML9, a multifunctional Arabidopsis thaliana calmodulin-like protein involved in stress responses and plant growth? Plant Signal Behav. 2012;7(9):1121-4. https://doi.org/10.4161/psb.21308

29. Vanderbeld B, Snedden WA. Developmental and stimulus-induced expression patterns of Arabidopsis calmodulin-like genes CML37, CML38 and CML39. Plant Mol Biol. 2007;64(6):683-97. https://doi.org/10.1007/s111 03-007-9189-0.

30. Munir S, Khan MR, Song J, Munir S, Zhang Y, Ye Z, et al. Genome-wide identification, characterization and expression analysis of calmodulin-like (CML) proteins in tomato (Solanum lycopersicum). Plant Physiol Biochem. 2016;102:167-79. https://doi.org/10.1016/j.plaphy.2016.02.020.

31. Grabherr MG, Haas BJ, Yassour M, Levin JZ, Thompson DA, Amit I, et al. Fulllength transcriptome assembly from RNA-Seq data without a reference genome. Nat Biotechnol. 2011;29(7):644-52. https://doi.org/10.1038/nbt.1883.

32. Love Ml, Huber W, Anders S. Moderated estimation of fold change and dispersion for RNA-seq data with DESeq2. Genome Biol. 2014;15(12):550. https://doi.org/10.1186/s13059-014-0550-8.

33. Xue C, Yao JL, Qin MF, Zhang MY, Allan AC, Wang DF, et al. PbrmiR397a regulates lignification during stone cell development in pear fruit. Plant Biotechnol J. 2019;17(1):103-17. https://doi.org/10.1111/pbi.12950.
34. Kanehisa M, Goto S. KEGG: Kyoto encyclopedia of genes and genomes. Nucleic Acids Res. 2000;28(1):27-30. https://doi.org/10.1093/nar/28.1.27.

35. Kanehisa M. Toward understanding the origin and evolution of cellular organisms. Protein Sci. 2019;28(11):1947-51. https://doi.org/10.1002/pro.371 5.

36. Kanehisa M, Furumichi M. SatoY, Ishiguro-Watanabe M, Tanabe M: KEGG: integrating viruses and cellular organisms. Nucleic Acids Res. 2021;49(D1): D545-51. https://doi.org/10.1093/nar/gkaa970.

37. Schulz P, Herde M, Romeis T. Calcium-dependent protein kinases: hubs in plant stress signaling and development. Plant Physiol. 2013;163(2):523-30. https://doi.org/10.1104/pp.113.222539.

38. Wieczorek J, Pietrzak M, Osowski A, Wieczorek Z. Determination of lead, cadmium, and persistent organic pollutants in wild and orchard-farm-grown fruit in northeastern Poland. J Toxicol Environ Health A. 2010;73(17-18): 1236-43. https://doi.org/10.1080/15287394.2010.492009.

39. Bivi MS, Paiko AS, Khairulmazmi A, Akhtar MS, Idris AS. Control of basal stem rot disease in oil palm by supplementation of calcium, copper, and salicylic acid. Plant Pathol J. 2016;32(5):396-406. https://doi.org/10.5423/PPJ.OA.03.2 016.0052.

40. Li $X$, Sun $Y$, Pan D, Wang $Y$, Cao J. The effect of $\mathrm{CaCl} 2$ marination on the tenderizing pathway of goose meat during conditioning. Food Res Int. 2017:102:487-92. https://doi.org/10.1016/j.foodres.2017.09.014.

41. Lee SH, Choi JH, Kim WS. Effect of calcium chloride spray on peroxidase activity and stone cell development in pear fruit (Pyrus pyrifolia 'Niitaka'). J Jpn Soc Hortic Sci. 2007;76(3):191-6. https://doi.org/10.2503/jjshs.76.191.

42. Tang $Y$, Zhao D, Meng J, Tao J. EGTA reduces the inflorescence stem mechanical strength of herbaceous peony by modifying secondary wall biosynthesis. Hortic Res. 2019;6(1):36. https://doi.org/10.1038/s41438-019-011 7-7.

43. El-Azaz J, de la Torre F, Pascual MB, Debille S, Canlet F, Harvengt L, et al Transcriptional analysis of arogenate dehydratase genes identifies a link between phenylalanine biosynthesis and lignin biosynthesis. J Exp Bot. 2020:71(10):3080-93. https://doi.org/10.1093/jxb/eraa099.

44. Martins V, Garcia A, Costa C, Sottomayor M, Geros H. Calcium- and hormone-driven regulation of secondary metabolism and cell wall enzymes in grape berry cells. J Plant Physiol. 2018;231:57-67. https://doi.org/10.1016/j. jplph.2018.08.011.

45. Miyamoto T, Takada R, Tobimatsu Y, Suzuki S, Yamamura M, Osakabe K, et al. Double knockout of OsWRKY36 and OsWRKY102 boosts lignification with altering culm morphology of rice. Plant Sci. 2020;296:110466. https:// doi.org/10.1016/j.plantsci.2020.110466.

46. Zhou J, Lee C, Zhong R, Ye ZH. MYB58 and MYB63 are transcriptional activators of the lignin biosynthetic pathway during secondary cell wall formation in Arabidopsis. Plant Cell. 2009;21(1):248-66. https://doi.org/10.11 05/tpc.108.063321

47. Felipo-Benavent A, Urbez C, Blanco-Tourinan N, Serrano-Mislata A, Baumberger N, Achard P, et al. Regulation of xylem fiber differentiation by gibberellins through DELLA-KNAT1 interaction. Development. 2018;145(23): 164962. https://doi.org/10.1242/dev.164962.

48. Ma R, Xiao Y, Lv Z, Tan H, Chen R, Li Q, et al. AP2/ERF transcription factor, li049, Positively Regulates Lignan Biosynthesis in Isatis indigotica through Activating Salicylic Acid Signaling and Lignan/Lignin Pathway Genes. Front Plant Sci. 2017;8:1361. https://doi.org/10.3389/fpls.2017.01361.

49. Reddy AS, Ali GS, Celesnik H, Day IS. Coping with stresses: roles of calciumand calcium/calmodulin-regulated gene expression. Plant Cell. 2011;23(6): 2010-32. https://doi.org/10.1105/tpc.111.084988

50. Kaneda M, Schuetz M, Lin BS, Chanis C, Hamberger B, Western TL, et al. ABC transporters coordinately expressed during lignification of Arabidopsis stems include a set of ABCBs associated with auxin transport. J Exp Bot. 2011;62(6):2063-77. https://doi.org/10.1093/jxb/erq416.

51. Alejandro $S$, Lee $Y$, Tohge $T$, Sudre D, Osorio S, Park J, et al. AtABCG29 is a monolignol transporter involved in lignin biosynthesis. Curr Biol. 2012; 22(13):1207-12. https://doi.org/10.1016/j.cub.2012.04.064

52. Liu Q, Luo L, Zheng L. Lignins: Biosynthesis and Biological Functions in Plants. Int J Mol Sci. 2018;19(2):335. https://doi.org/10.3390/ijms19020335.

\section{Publisher's Note}

Springer Nature remains neutral with regard to jurisdictional claims in published maps and institutional affiliations. 